\title{
RESEARCH ON THE QUALITY OF THE WELDED JOINT OF ALUMINIUM ALLOY SHEET AA6082-T6 USING FSW, MIG AND TIG METHODS
}

\author{
RAZISKAVE KAKOVOSTI VARJENEGA SPOJA PLOČEVINE IZ \\ ALUMINIJEVE ZLITINE AA6082-T6, Z METODAMI FSW, MIG IN
} TIG

\author{
Nikola Šibalić, Milan Vukčević \\ University of Montenegro, Faculty of Mechanical Engineering, Dzordza Vasingtona bb, 81000 Podgorica, Montenegro \\ Prejem rokopisa - received: 2018-10-18; sprejem za objavo - accepted for publication: 2019-04-24
}

doi:10.17222/mit.2018.224

\begin{abstract}
This is an experimental research of the welding AA6082-T6 aluminium alloy sheet, thickness $7.8 \mathrm{~mm}$, with different kinds of methods: FSW, MIG and TIG. The goal is to test the quality of the welded joints, i.e., to determine the mechanical parameters of the joining process of the metals obtained with conventional and non-conventional methods. The research is more oriented towards the non-conventional FSW method, because it is more common in modern industry. Wider research is done based on an adopted multifactorial experimental plan with a variation of factors on two levels. The parameters that have been changed are as follows: welding speed $(\mathrm{mm} / \mathrm{min})$, rotation speed of tools $\left(\mathrm{min}^{-1}\right)$, angle of pin slope $\left(^{\circ}\right)$, diameter of pin $(\mathrm{mm})$ and diameter of shoulder $(\mathrm{mm})$. The tools that are used in the experiment have a conical shape. A professional welding machine with a technology that is based on known parameters, i.e., amperage (A), filler, number of passes, shape of the groove, etc. is used with the MIG and TIG methods in the experiment. A detailed analysis of the obtained mechanical parameters (tensile strength and impact toughness) for all three methods of the welding (FSW, MIG and TIG) is provided.

Keywords: aluminium alloy, tensile strength, impact toughness
\end{abstract}

V članku je predstavljena eksperimentalna študija varjenja pločevine iz aluminijeve zlitine AA6082-T6, debeline 7,8 mm, z uporabo varilnih postopkov FSW, MIG in TIG. Namen prispevka je preveriti kakovost zvarjenih spojev, tj. določiti mehanske parametre postopka spajanja kovin, pridobljenih s konvencionalnimi in nekonvencionalnimi metodami. Ker se proces FSW vse pogosteje uporablja v sodobni industriji, je poudarek raziskave na nekonvencionalnem procesu FSW, kje so opravljene širše raziskave, ki temeljijo na sprejetemu večfaktorskemu eksperimentalnemu načrtu, z različnimi faktorji dveh ravni. Parametri, ki so spreminjali, so: hitrost varjenja $(\mathrm{mm} / \mathrm{min})$, vrtenje orodja $\left(\mathrm{min}^{-1}\right)$, naklon zatiča orodja $\left(^{\circ}\right)$, premer zatiča orodja $(\mathrm{mm})$ in premer ramenskega orodja $(\mathrm{mm})$. Orodje, uporabljeno v eksperimentu, je v obliki stožca. V postopkih MIG in TIG se v poskusu uporabljajo profesionalni varilni stroji z znano tehnologijo, ki temelji na znanih parametrih: tokovna trdnost (A), dodajanje materiala, število prehodov, oblika žlebov in tako naprej. V prispevku je predstavljena podrobna analiza dobljenih mehanskih parametrov (natezna trdnost in udarna žilavost) za vse tri varilne procese (FSW, MIG in TIG).

Ključne besede: aluminijeve zlitine, natezna trdnost, udarna žilavost

\section{INTRODUCTION}

The non-conventional method of joining the similar and dissimilar materials, Friction Stir Welding - FSW, was patented by The Welding Institute (TWI) from Great Britain in December 1991, and was found by Wayne M. Thomas, who successfully joined aluminium alloys. ${ }^{1-6}$ The new method of joining is performed in the solid state without melting the material. It is an ecologically clean process, there are no harmful fumes as in conventional procedures, and no light flash that characterizes all conventional procedures. Also, the process is energy efficient because energy is not consumed for melting metals, but only for starting the rotary electric motor of the machine, in our case a milling machine. Therefore, the application of this process for industrial purposes is ex-

*Corresponding author's e-mail: nikola@ucg.ac.me tremely cost-effective and significant savings in electricity are achieved..$^{7-12}$

The FSW procedure starts with the tool positioned above the milling machine's working table, and its axis is normal on the joining line of the sheet metals. The rotating tool slowly accesses the line of the joint and heats up into the material - workpieces. Consequently, in the material (workpieces), the initial hole is formed, whereby the heat is being generated. The pin is screwed into the material until the shoulder makes contact with the upper surface of the workpieces. The material must be kept inside the welding zone with sufficient pressure to create sufficient temperature for the FSW process to run without interruption. In this position, the tool heats the material up to the point of melting and becomes plastic. Due to the shape of the pin the heated material moves around it and thus stirs. Then the longitudinal movement of the machine's working table starts. In the further course of the FSW process, the pin practically "slides" between the 
sheet metals in the direction of welding, the new material is heated, becomes plastic and is continuously stirred (Figure 1). At the same time, behind the shoulder, a groove of smooth warmed material, which is cooled and solidified, is formed, and between the sheet metals (workpieces), a monolithic compound is formed, while the lower plane is formed by the substrate on which the workpieces stand and it is smooth and straight. ${ }^{13}$

Conventional welding methods, Metal Inert Gas MIG and Tungsten Inert Gas - TIG are arc welding methods. In the MIG method, an electric arc is established between the filler and the basic material. The filler is a wire that is continuously brought and melted. In the TIG method the electric arc is established between the insoluble tungsten electrode and the basic material. Both methods use inert-gas protection and can be successfully applied for welding aluminium and its alloys. ${ }^{14,15}$ In these methods materials melt, which leads to the consumption of large amounts of energy and as a product of that, distortion of the material occurs. Also, there is light flash, evaporation and radiation.

\section{EXPERIMENTAL PART}

\subsection{Material}

The material used in the experiment is a sheet of aluminium alloy AlSi1MgMn, numerical label AA6082-T6, whose chemical composition is determined on two samples using the "General Metal Analyzer - Niton x12" (Table 1), which determines the chemical composition on the principle of ionizing radiation. The nominal mechanical properties of the joined material are an ultimate tensile strength of $R_{\mathrm{m}}=340 \mathrm{MPa}$, yield stress of $R_{\mathrm{p} 0,2}=$ $310 \mathrm{MPa}$, elongation of $A 5=11 \%$ and melting point is $555{ }^{\circ} \mathrm{C} .{ }^{16}$ The dimension of the workpiece was $200 \mathrm{~mm}$ $\times 50 \mathrm{~mm} \times 7.8 \mathrm{~mm}$.

Table 1: Chemical composition of the used alloy AA6082-T6, in mass fractions $(w / \%)$

\begin{tabular}{|c|c|c|c|c|c|c|c|c|c|c|}
\hline $\mathrm{Al}$ & $\mathrm{Fe}$ & $\mathrm{Si}$ & $\mathrm{Ti}$ & $\mathrm{Cu}$ & $\mathrm{Zn}$ & $\mathrm{V}$ & $\mathrm{Cr}$ & $\mathrm{Mn}$ & $\mathrm{Mg}$ & $\mathrm{Na}$ \\
\hline 98.25 & 0.22 & 0.85 & 0.01 & 0.002 & 0.062 & 0.006 & 0.001 & 0.16 & 0.43 & 0.002 \\
\hline 98.29 & 0.21 & 0.83 & 0.01 & 0.002 & 0.060 & 0.006 & 0.001 & 0.15 & 0.43 & 0.001 \\
\hline
\end{tabular}

\subsection{Experimental procedure}

A milling machine is used for the FSW method and a professional welding machine "Varstroj 350" and "ESAB Tig 3000i AC/DC" were used, respectively, for the MIG and TIG methods.

In the FSW method, a rotational tool with a conical pin (Figure 2a) was made of 1.2343 steel and heat treated to increase its hardness to $58 \mathrm{HRC}$. The dimensions of the tool are shown in Figure $\mathbf{2 b}$.

Based upon a preliminary investigation, the 2-level factorial orthogonal plan with four enter points $\left(n_{0}=4\right)$ was adopted. As the input values, the elements of the welding regime and the geometric factors of the tool

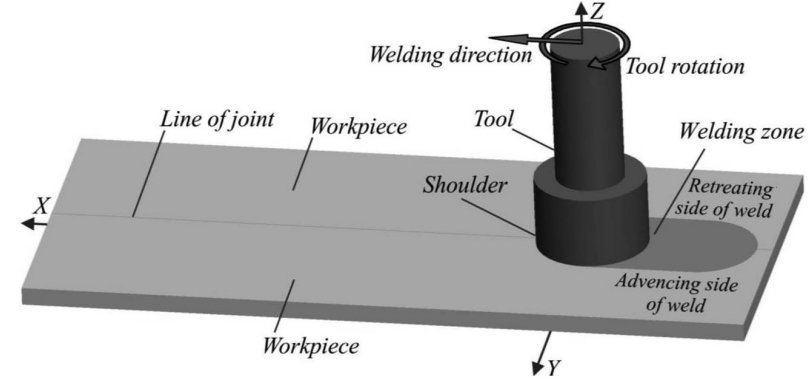

Figure 1: Tool and workpiece

were chosen with adopted levels of variation of the input factors:

$X_{1}=v(200 \mathrm{~mm} / \mathrm{min} ; 80 \mathrm{~mm} / \mathrm{min} ; 125 \mathrm{~mm} / \mathrm{min})$ welding speed,

$X_{2}=\omega\left(1000 \mathrm{~min}^{-1} ; 630 \mathrm{~min}^{-1} ; 800 \mathrm{~min}^{-1}\right)$ rotation speed of tool,

$X_{3}=\alpha\left(5^{\circ} ; 3^{\circ} ; 3.87^{\circ}\right)$ angle of pin slope,

$X_{4}=d(7 \mathrm{~mm} ; 5 \mathrm{~mm} ; 5.92 \mathrm{~mm})$ pin diameter,

$X_{5}=D(28 \mathrm{~mm} ; 25 \mathrm{~mm} ; 26.46 \mathrm{~mm})$ diameter of the shoulder.

The research site for the FSW method was located at the laboratory of the Faculty of Mechanical engineering.

A sample welded with the FSW method was obtained at the central point of the orthogonal experimental plan (Figure 3a), and is compared with the sample welded with the conventional methods MIG (Figure 3b) and TIG (Figure 3c).

With the MIG method, argon as the inert gas and a direct current with reversed polarity $\operatorname{DCEP}(+)$ were used. The preparation of workpieces, made out of aluminium alloys, was carried out, where the $\mathrm{V}$ groove was made, with standard dimensions: groove angle $60^{\circ}$, height of the root of the groove $1 \mathrm{~mm}$ and gap $2 \mathrm{~mm}$ with the cutting treatment. The welding is done in two passes. A wire with a standard diameter of $2.4 \mathrm{~mm}$, which by its characteristics is appropriate for the basis material, is taken for the filler material. The wire feed speed is 3 $\mathrm{m} / \mathrm{min}$, and the amperage $280 \mathrm{~A}$. No preheating of the
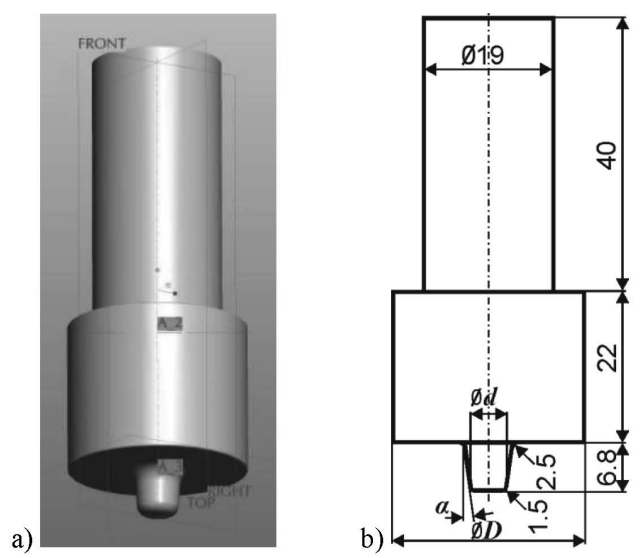

Figure 2: Tool with adopted dimensions and parameters $D, d$ and $\alpha$ 
a)

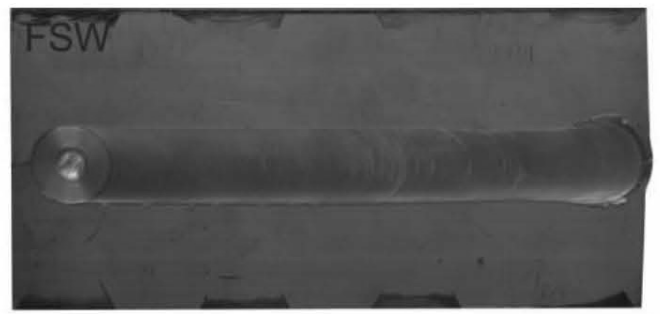

b)

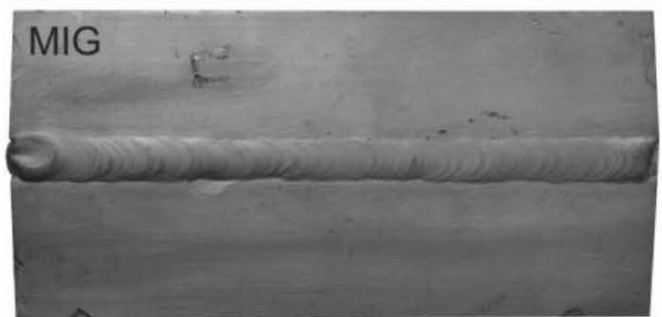

c)

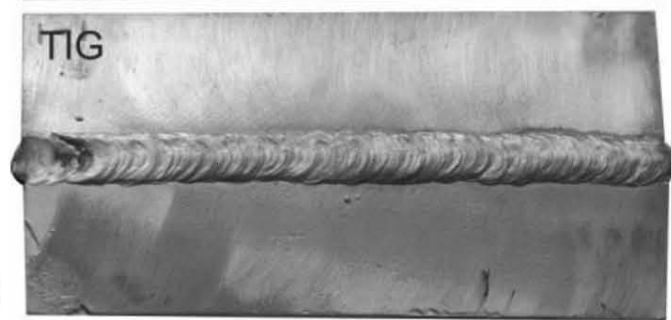

Figure 3: Welded workpieces (FSW, MIG and TIG)

material was performed. The cooling was done in the air. The welded sample is shown in Figure $\mathbf{3 b}$.

With the TIG method, argon was also used as the inert gas with an alternating current. On the workpieces made out of aluminium alloys, the exact same $\mathrm{V}$ groove, standard dimensions, were made. The welding was done in two passes. An insoluble tungsten electrode was used (green tungsten $\phi 4.0 \mathrm{~mm} \times 1.75 \mathrm{~mm}$ ). Wire with a standard diameter $4.8 \mathrm{~mm}$, which by its characteristics is compatible with basic material, is taken for the filler. The wire feed speed is $3 \mathrm{~m} / \mathrm{min}$, and the amperage is $300 \mathrm{~A}$. Preheating of the material was carrie dout, at the temperature of $180{ }^{\circ} \mathrm{C}$. Cooling was done in the air. The welded sample is shown in Figure 3c.

\section{MECHANICAL TESTING}

For the mechanical research, cutting of the specimens from the welded joint was done. It was performed with a "Water Jet", so that there is no heat transfer during the cutting processing.

The tensile and toughness properties of the welded workpiece were investigated. All the specimens were taken from welded joint directions relative (normal) to the weld. The arrangement of specimens in the welded workpieces was made according to the standard for testing of welded joints according to the scheme shown in Figure 4a. Cut out specimens for FSW method on which the samples for determining the tensile strength based on two ISO and GOST standards, samples for the determination of impact toughness, as well as microstructural
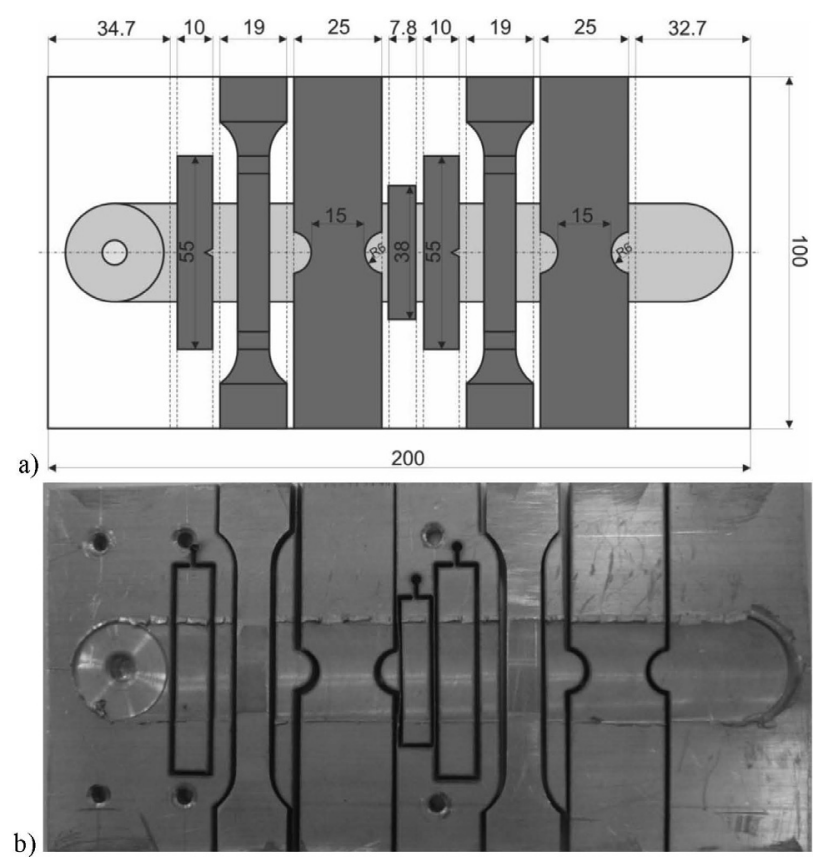

Figure 4: Position of the specimens for tensile and impact tests, which were cut out from the welded workpiece

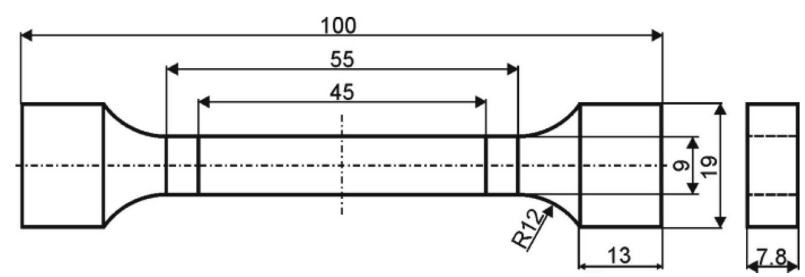

Figure 5: Specimen - Schematic view ${ }^{17}$

tests are shown in Figure 4b. In this paper, samples for the tensile strength and the impact toughness according to the ISO standard were used.

\subsection{Determination of tensile strength}

The tensile test was carried out on the $200-\mathrm{kN}$ tensile machine. Testing was conducted at room temperature.

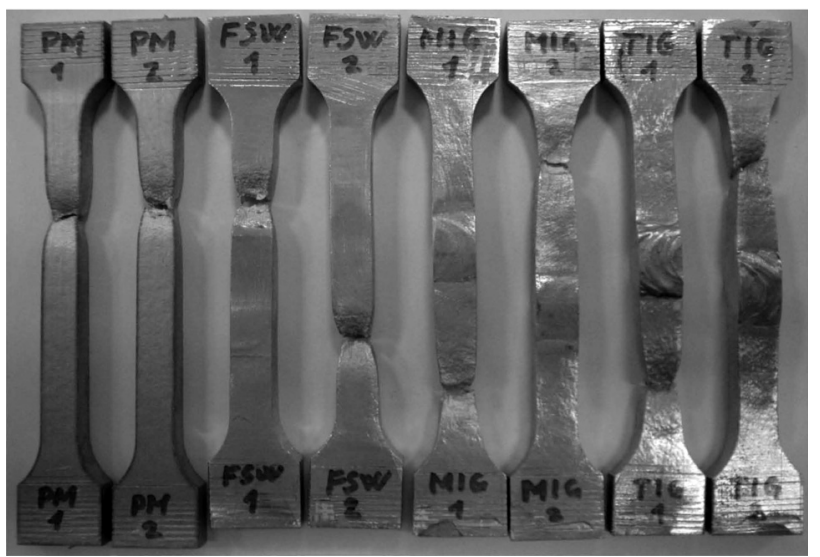

Figure 6: Specimen for tensile testing (1) and (2): PM - parent (base) material, FSW, MIG and TIG 


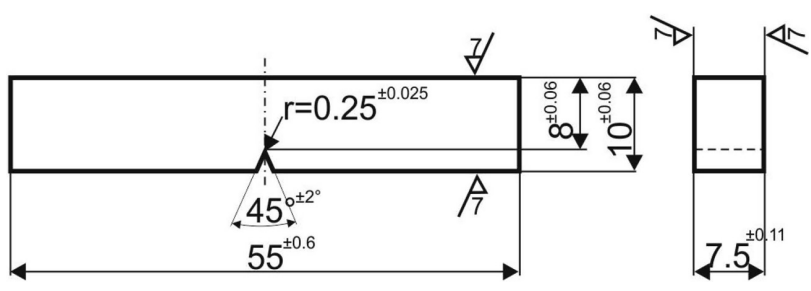

Figure 7: Test specimens for impact toughness testing

All the specimens are made according to the standard EN 10002-1:2008 (Figure 5). ${ }^{17}$ In Figure 6, the specimens obtained by the FSW, MIG, TIG, as well as the parent material, are shown.

\subsection{Determination of impact toughness}

Testing the toughness of the welded material is carried out by impact load on a Sharp's pendulum, with a maximum initial energy of $150 \mathrm{~J}$.

The test specimens of a particular shape and dimensions were broken with one impact. During the impact the test specimen is exposed to bending. The aim of the test is to determine the impact toughness of the material welded by the FSW, MIG and TIG methods.

The toughness of the welded material or impact strength during the bending is spent work for the breakdown of the test specimens reduced to the unit of the cross-section of the test specimens:

$$
r=\frac{N}{A} \mathrm{~J} / \mathrm{cm}^{2}
$$

The test specimen was made according to the standard EN 10045-1:1993 (Figure 7). ${ }^{18}$ A narrow test specimens with a $\mathrm{V}$ notch was adopted. ${ }^{18}$

The testing was performed at the room temperature and the values of impact toughness are given in Table 2.

Table 2: The obtained values of impact toughness

\begin{tabular}{|c|c|c|}
\hline No. & Spent energy $(J)$ & $\rho\left(\mathrm{J} / \mathrm{cm}^{2}\right)$ \\
\hline PM1 & KV $150 / 10=42$ & 70.00 \\
\hline PM2 & KV 150/10 $=42$ & 70.00 \\
\hline FSW1 & KV 150/10 $=38$ & 63.33 \\
\hline FSW2 & KV 150/10 $=38$ & 63.33 \\
\hline MIG1 & KV 150/10 $=31$ & 51.66 \\
\hline MIG2 & KV 150/10 $=32$ & 53.33 \\
\hline TIG1 & KV 150/10 $=26$ & 43.33 \\
\hline TIG2 & KV $150 / 10=28$ & 46.66 \\
\hline
\end{tabular}

\section{RESULTS AND DISCUSSION}

The FSW method in its realization and basic characteristics has significant advantages over the conventional methods MIG and TIG. No filler material is needed, no protective gas and no preparation of the workpiece, which allows relatively simple realization and gives economic advantages to the FSW method. For its main realization of the process, the FSW method has ecological gains, some of them are: there are no harmful vapours, radiation and light flash. Nowadays, it has special meaning because of the harsh environmental regulations, and we also have a better quality of the welded joint.

The testing of the quality of the welded joint is a complex task and is carried out through the examination of the mechanical and microstructural characteristics of the welded joint. The aim is that these characteristics be as close as possible to the corresponding values of the parent material.

The main focus of this study is a determination of the mechanical characteristics for the tensile strength and the impact toughness of the welded joint obtained by previously defined methods: FSW, MIG and TIG. For the FSW method, at the central point of the plan with welding parameters (welding speed: $125 \mathrm{~mm} / \mathrm{min}$, rotation speed of tools: $800 \mathrm{~min}^{-1}$, angle of pin slope $3.87^{\circ}$, diameter of pin $5.92 \mathrm{~mm}$ and diameter of shoulder $26.46 \mathrm{~mm}$ ) the values for the tensile strength of specimen (1) and (2) were obtained and are given at Table 3. Also, the tensile strength values obtained by the MIG and TIG method for samples (1) and (2), as well as the parent material samples (1) and (2), are given in Table 3.

Table 3: The obtained values of tensile strength

\begin{tabular}{|c|c|c|}
\hline$R_{\mathrm{m}}$ & Specimen $(1)(\mathrm{MPa})$ & Specimen $(2)(\mathrm{MPa})$ \\
\hline$R_{\mathrm{mFSW}}$ & 332.97 & 339.77 \\
\hline$R_{\mathrm{mMIG}}$ & 329.06 & 331.27 \\
\hline$R_{\mathrm{mTIG}}$ & 284.01 & 293.80 \\
\hline$R_{\mathrm{mPM}}$ & 352.56 & 352.91 \\
\hline
\end{tabular}

The stress-elongation diagram for the used methods of welding and for the parent material is given in Figure 8.

From the diagram one can see that the tensile strength has the greatest value at the joint welded with the FSW method, then MIG method and the smallest value at the joint welded with TIG method. The obtained values of the impact toughness from Table 2 , one can

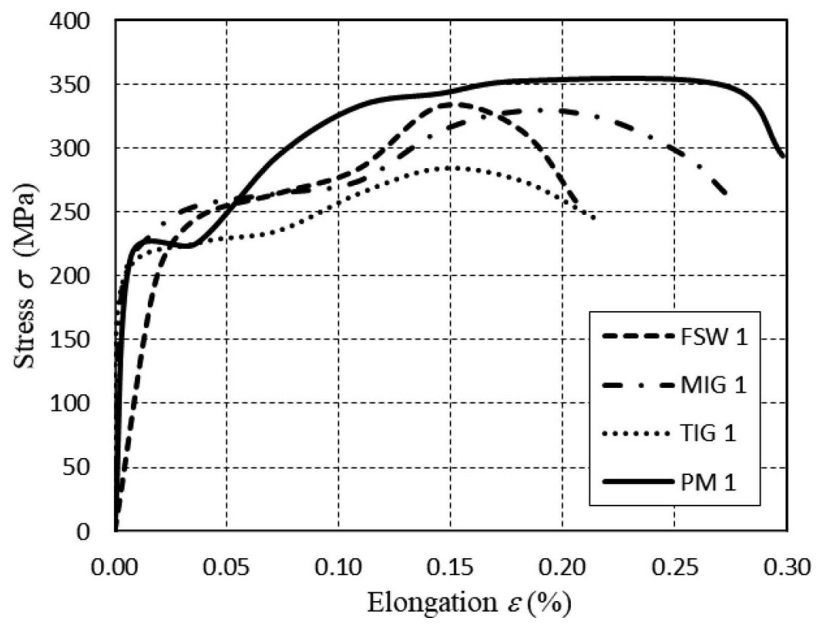

Figure 8: Diagram: Stress-elongation for specimens (1) 
see that the greatest value is for the samples obtained by from FSW method, then MIG method and the smallest value has the TIG method.

In order to make the analysis of the results when determining the quality of the welded joint, the relationship between tensile strength and impact toughness of the welded joint and parent material was determined (Table 4).

Table 4: The ratio between $R_{\mathrm{m}}$ and $\rho$ of the welded joint and parent material

\begin{tabular}{|c|c|c|}
\hline Ratio & Specimen (1) & Specimen $(2)$ \\
\hline$R_{\mathrm{mFSW}} / R_{\mathrm{mPM}}$ & 0.9444 & 0.9722 \\
\hline$R_{\mathrm{mMIG}} / R_{\mathrm{mPM}}$ & 0.9333 & 0.9448 \\
\hline$R_{\mathrm{mTIG}} / R_{\mathrm{mPM}}$ & 0.8055 & 0.8333 \\
\hline$\rho_{\mathrm{FSW}} / \rho_{\mathrm{PM}}$ & 0.9047 & 0.9047 \\
\hline$\rho_{\mathrm{MIG}} / \rho_{\mathrm{PM}}$ & 0.7380 & 0.7618 \\
\hline$\rho_{\mathrm{TIG}} / \rho_{\mathrm{PM}}$ & 0.6190 & 0.6665 \\
\hline
\end{tabular}

\section{CONCLUSIONS}

From the aspect of the quality of the welded joint aluminium alloy AA6082-T6 and the determination of mechanical characteristics, the greatest similarity to the parent material is for specimens (1) and (2) obtained with FSW method, which indicates that this method produces a better quality of the welded joint. The greatest proximity of the tensile strength to the parent material $\left(R_{\mathrm{mFSW}} / R_{\mathrm{mPM}}=0.9722\right)$ was obtained for the compounds welded by the FSW method. Analogously, the greatest proximity of the impact strength to the parent material $\left(\rho_{\mathrm{FSW}} / \rho_{\mathrm{PM}}=0.9047\right)$ was obtained for compounds welded by the FSW method. The values of the ratio of the tensile strength and the parent material are less by $2.00 \%$ for MIG and $14.49 \%$ for TIG compared to the FSW. The values of the ratio of the impact toughness and the parent material are less by $17.11 \%$ for the MIG, and $28.97 \%$ for TIG compared to the FSW.

The temperature field that occurred while using the MIG and TIG methods is causing workpieces to suffer large distortion, which can be observed during the welding process.

The results of the research show that in the case of butt welding joint of the aluminum alloy AA6082-T6, the FSW method has an pronounced advantage over the conventional methods.

\section{REFERENCES}

${ }^{1}$ W. M. Thomas, E. D. Nicholas, J. C. Needham, M. G. Murch, P. Temple-Smith, C. J. Dawes, Friction stir butt welding, 1995, U.S. Patent, US5460317A No. 5,460, 317

${ }^{2}$ R. S. Mishra, Z. Y. Ma, Frictions stir welding and processing, Materials Science and Engineering R, 50 (2005) 1-2, 1-78, doi:10.1016/j.mser.2005.07.001

${ }^{3}$ R. Palanivel, R. F. Laubscher, I. Dinaharan, N. Murugan, Developing a friction-stir welding window for joining the dissimilar aluminum alloys AA6351 and AA5083, Mater. and Tehnol., 51 (2017) 1, 5-9, doi:10.17222/mit.2015.049

${ }^{4}$ S. M. Bayazida, H. Farhangia, A. Ghahramania, Effect of pin profile on defects of friction stir welded 7075 aluminum alloy, Procedia Materials Science, 11 (2015), 12-16, doi:10.1016/j.mspro.2015.11.013

${ }^{5}$ H. Basak, K. Kaptan, Effects of different stirrer-pin forms on the joining quality obtained with friction-stir welding, Mater. Tehnol., 49 (2015) 5, 693-701, doi:10.17222/mit.2014.062

${ }^{6}$ R. Palanivel, P. K. Matthews, The tensile behaviour of friction-stir-welded dissimilar aluminium alloys, Mater. Tehnol., 45 (2011) 6, 623-626

${ }^{7}$ A. Reynolds, Visualization of material flow in autogenous friction stir welds, Science and Technology of Welding and Joining, 5, (2000) 2, 120-124, doi:10.1179/136217100101538119

${ }^{8}$ R. K. Uyyuru, S. V. Kailas, Numerical analysis of friction stir welding process, Journal of Materials Engineering and Performance, 15, (2006) 5, 505-518, doi:10.13.61/105994906X136070

${ }^{9}$ A. Kubit, R. Kluz, K. Ochalek, D. Wydrzynski, T. Trzepiecinski, Friction stir welding of 2024-T3 aluminium alloy sheet with sheet pre-heating, Mater. Tehnol., 52 (2018) 3, 283-288, doi:10.17222/ mit.2017.084

${ }^{10}$ S. W. Chang, S. R. Rajesh, K. C. Chun, J. H. Kim, Microstructure and mechanical properties of hybrid laser - friction stir welding between AA6061-T6 Al alloy and AZ31 Mg alloy, Journal of Materials Science \& Technology, 27, (2011) 3, 199-204, doi:10.1016/S1005-0302(11)60049-2

${ }^{11}$ Y. Bozkurt, Weldability of metal matrix composite plates by friction stir welding at low welding parameters, Mater. Tehnol., 45 (2011) 5, 407-412

${ }^{12}$ Z. Shen, Y. Ding, J. Chen, L. Fu, X. C. Liu, H. Chen, W. Guo, A. P. Gerlich, Microstructure, static and fatigue properties of refill friction stir spot welded 7075-T6 aluminium alloy using a modified tool, Science and Technology of Welding and Joining, doi:10.1080/13621718.2019.1572300

${ }^{13}$ N. Sibalic, M. Vukcevic, M. Damjanovic, A. Koprivica, Examination of microstructure of welded joint of similar materials, obtained by FSW method, The Inter. Conf. on Materials Processing Technology, Bangkok, 2017, 164-169

${ }^{14}$ R. Sacks, E. Bohnart, Welding principles and practices, $3^{\text {rd }}$ ed., McGraw-Hill, New York 2005

${ }^{15}$ D. Klobcar, L. Kosec, A. Pietras, A. Smolej, Friction-stir welding of aluminium alloy 5083, Mater. Tehnol., 46 (2012) 5, 483-488

${ }^{16} \mathrm{https}$ ://www.thyssenkrupp-materials.co.uk/aluminium-6082.html, 13.09.2018

${ }^{17}$ EN 10002-1:2008 Metallic materials - Tensile testing - Part 1, Method of test at ambient temperature, Brussels

${ }^{18}$ EN 10045-1:1993 Mechanical testing of metals - Sharpy impact test - Part 1, Test method, Brussels 